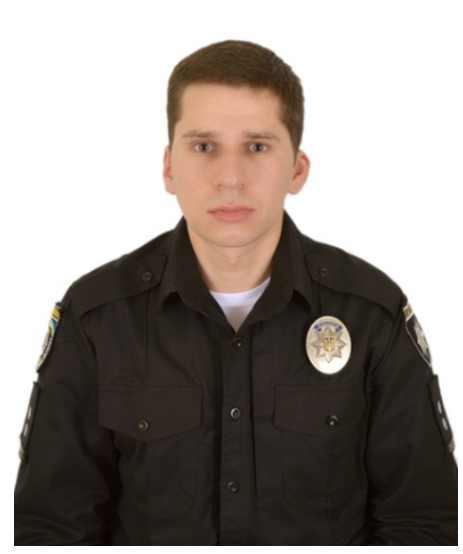

Потоцький Мирослав Михайлович, ад'юнкт

(Донецький юридичний інститут МВС України, м. Кривий Ріг)

ORCID: https://orcid.org/0000-0002-2979-9114

\section{ФУНКЩІОНАЛЬНЕ ПРИЗНАЧЕННЯ КРИМІНАЛЬНОГО ПРОЦЕСУАЛЬНОГО ЗАТРИМАННЯ}

Статтю присвячено дослідженню фрункціонального призначення затримання особи в кримінальному провадженні. Зазначено, що дослідження фуункціонального призначення затримання є необхідним для розуміння сутності застосування затримання в кримінальному процесі. Виділено п'ять фьункцій кримінального процесуального затримання: припинення кримінальних правопорушень; інфрормаційне забезпечення початкового етапу кримінальної процесуальної діяльності; забезпечення проведення першочергових процесуальних дій за участю затриманого; запобігання неналежній поведінці підозрюваного на первісному етапі розслідування; створення умов для вирішення питання про застосування або зміну запобіжного заходу. Надано процесуальну характеристику кожній із них.

Ключові слова: затримання; підозрюваний; фуункціональне призначення; уповноважена службова особа; злочин; припинення.

Постановка проблеми. Затримання особи $є$ важливим аспектом кримінальної процесуальної діяльності. Без застосування затримання сторона обвинувачення втратить дієвий інструмент впливу на процесуальні відносини, що, зі свого боку, матиме наслідком невиправдані складнощі в притягненні осіб до кримінальної відповідальності. Дослідження функціонального призначення затримання $є$ необхідним для розуміння сутності та підвищення законності застосування затримання в практичній діяльності.

Аналіз останніх досліджень та публікацій. Окремі проблемні питання затримання особи в кримінальному провадженні досліджували вчені: О. І. Білоусов, А. Ф. Волобуєв, Д. В. Лазарева, Т. О. Лоскутов, Ю.В.Лук'яненко, Є. І. Макаренко, В. О. Малярова, В. В. Рожнова, С. М. Смоков, О. В. Шульга, О. О. Юхно та інші. Незважаючи на достатню кількість наукових праць та розробок щодо затримання особи в кримінальному провадженні, варто зазначити, що дослідження функціонального призначення затримання не знайшло належного відображення в науковій літературі.

Метою статті $\boldsymbol{\epsilon}$ аналіз функціонального призначення затримання особи в кримінальному провадженні. Завдання дослідження можна окреслити так: визначення функцій затримання особи в кримінальному провадженні; надання процесуальної характеристики кожній із них (курсив мій. - М. П.)

Виклад основного матеріалу. Затримання особи в кримінальному провадженні виконує низку функцій, поміж яких: 1) припинення кримінальних правопорушень; 2) інформаційне забезпечення початкового етапу кримінальної процесуальної діяльності; 3) забезпечення проведення першочергових процесуальних дій за участю затриманого; 4) запобігання неналежній поведінці підозрюваного на первісному етапі розслідування; 5) створення умов 
Розглянемо функції більш детально.

1. Припинення кримінальних правопорушень. Одним із завдань кримінального провадження є захист особи, суспільства та держави від кримінальних правопорушень; охорона прав, свобод та законних інтересів учасників кримінального провадження [1]. Припинення кримінальних правопорушень $є$ однією з головних функцій такої процесуальної дії, як затримання особи. Конституція України допускає застосування затримання особи в разі нагальної необхідності запобігти злочинові чи його припинити [2]. Відповідно до п. (с) ч. 1 ст. 5 Конвенції про захист прав людини і основоположних свобод, особу може бути затримано, якщо обгрунтовано вважається необхідним запобігти вчиненню нею правопорушення чи ії втечі після його вчинення [3].

У Кримінальному процесуальному кодексі України (далі - КПК України) передбачено виконання такої функції шляхом закріплення в ст. 208 положення, відповідно до якого уповноважена службова особа має право затримати особу, якщо ії застали під час вчинення злочину чи замаху на його вчинення. Ст. 207 КПК України регламентує: кожен має право затримати будь-яку особу (крім винятків, передбачених КПК України), якщо цю особу застали при вчиненні або замаху на вчинення кримінального правопорушення [1]. Законодавець, закріплюючи такі положення, підкреслює суспільну важливість та соціальну необхідність таких дій.

Під затриманням традиційно розуміється конкретна та цілеспрямована діяльність правоохоронних органів та громадян із припинення злочинів і взяття злочинців під варту [4, c. 83]. В. І. Борман наголошує на важливості інституту затримання, оскільки, завдяки затриманню, можна припинити кримінальне правопорушення, тим самим урятувати життя, здоров'я, майно від злочинних посягань [5, с. 18-19].

Ситуації для затримання особи «на гарячому» виникають раптово, мають переважно очевидний характер та сприймаються уповноваженими службовими особами (громадянами під час громадського арешту) у момент вчинення злочину. За вказаних умов в уповноважених службових осіб виникає необхідність негайного припинення протиправних дій [6, с. 39]. Досягнення такої мети можливе лише шляхом затримання особи.

Отже, затримання особи є негайною реакцією (у формі припинення злочинних дій) на факт виявлення кримінального правопорушення за наявності мінімального набору даних про особу, яка його вчинила. Це проявляється в наданні уповноваженою службовою особою відповідного наказу чи фізичному захопленні підозрюваного, що не дозволило при цьому йому втекти. У зв'язку із припиненням протиправних дій (шляхом обмеження права на свободу та особисту недоторканність), унеможливлюється подальша злочинна діяльність.

2. Інформаційне забезпечення початкового етапу кримінальної процесуальної діяльності. Для початкового етапу розслідування $є$ характерним вирішення завдань, як-от: установлення місця, часу, обставин злочину; виявлення, фіксація та вилучення його слідів; з'ясування, розшук та затримання підозрюваних; збирання доказів, достатніх для пред'явлення обвинувачення [7, с. 35].

Затримання становить специфічну сукупність пізнавальних і посвідчувальних операцій, спрямованих на отримання фактичних даних і відомостей про обставини кримінального провадження [8, с. 12]. Затримання особи охоплює широкий спектр методів пізнання, бо містить елементи безпосереднього візуального спостереження, огляду, особистого обшуку й пояснень особи [9, с. 32].

У момент затримання не завжди є зрозумілим, чи вчинене кримінальне правопорушення (а якщо так, то яке саме), чи дійсно затриманий має відношення до правопорушення, чи $є$ він осудним та інші обставини $[10$, с. 4]. За допомогою затримання вже на первинному етапі можуть підтверджуватися чи спростовуватися дані про можливе вчинення кримінального правопорушення та 3'ясування відношення затриманого до його вчинення. Також може бути отримана оперативна інформація про наявність співучасників злочину, місце знаходження жертви й викраденого майна; інша інформація, яка має суттєве значення на розглядуваному етапі кримінального провадження. 
Затримання особи «на гарячому» може надати стільки доказової інформації, скільки неможливо було б отримати іiі за допомогою інших подальших процесуальних дій (огляду, обшуку).

Час і місце затримання є відомостями, що безпосередньо пов'язують кримінальне правопорушення і особу затриманого. Просторово-часові дані затримання особи на місці вчинення правопорушення вказують на ймовірну причетність затриманої особи до протиправного діяння [11, с. 102].

3 метою отримання носіїв доказової інформації, захоплення особи здійснюється під час проведення оперативно-розшукових заходів [8, с. 13]. Прикладом може слугувати завчасно сплановане затримання хабарника «на гарячому» - у мить одержання хабара або відразу ж після цього, що є одним із дієвих способів його викриття. Затримання «на гарячому» здійснює настільки разючий психологічний вплив на хабарника, що він, як правило, без вагань сам себе викриває в інкримінованому злочині [12, с. 305].

Пізнавальну мету затримання особи в кримінальному провадженні не варто заперечувати [13, с. 134]. Затримання особи може нести в собі самостійну доказову інформацію, що має значення на початковому етапі розслідування. Ідеться, по-перше, про фіксацію в протоколі затримання підстав для затримання, обстановки затримання (точного часу, місця затримання); по-друге, про докладний опис затриманого та його фотознімок; потретє, про закріплення інших даних, що мають значення для кримінального провадження.

У разі, коли затримання пов'язано з безпосереднім виявленням ознак злочину, наведені вище дані набувають особливого значення для встановлення обставин кримінального провадження [8, с. 12].

3. Забезпечення проведення першочергових процесуальних дій за участю затриманого. Затримання особи створює необхідні передумови для виявлення та закріплення доказів шляхом проведення слідчих (розшукових) дій та інших процесуальних дій, які проводяться одночасно чи відразу після затримання [6, с. 64]. Такими процесуальними діями можуть виступати особистий обшук затриманого, примусове освідування, пред'явлення підозрюваного чи викрадених речей для впізнання, примусове отримання зразків для проведення експертиз тощо.

Як форма оперативного реагування на протиправні дії своєчасне затримання особи багато в чому зумовлює результативність подальшого досудового розслідування [6, с. 65]. Показання особи, що надані відразу після захоплення, можуть мати важливе значення в процесі подальшого розслідування [8, с. 12].

Однією із цілей затримання є забезпечення перебування особи в місці провадження справи [14, с. 88], чим і забезпечується участь затриманого в процесуальних діях. У результаті особистого обшуку затриманого може бути здобута інформація, яка відіграє суттєву роль на початковому етапі провадження. Можуть бути вилучені знаряддя вчинення правопорушення, речі, що були отримані протиправним шляхом, інші предмети матеріального світу, які мають значення для кримінального провадження і яких можна швидко позбутися.

4. Запобігання неналежній поведінці підозрюваного на первісному етапі розслідування. Заходи процесуального примусу мають на меті або запобігти неналежній поведінці, або забезпечити відповідну поведінку окремих учасників кримінального процесу [11, с. 92]. Маючи характер невідкладної процесуальної дії, затримання найчастіше застосовується на початковому етапі розслідування, коли доказів для обрання запобіжного заходу ще недостатньо, а необхідність ізоляції підозрюваного для уповноваженої службової особи очевидна $[15$, с. 48$]$.

Неналежна поведінка підозрюваного має на меті протидіяти розслідуванню. Протидія розслідуванню - це діяння особи, спрямовані на створення перешкод у встановленні обставин уже виявленого злочину в умовах розпочатого його розслідування. Протидія проявляється у виборі певної лінії поводження, учиненні активних дій, спрямованих на створення перешкод у збиранні та використанні доказів органом слідства та судом [16, с. 95]. У випадку, коли особа, яка вчинила правопорушення, не залишається на місці вчинення протиправного діяння 
(здебільшого), логічним є припущення про те, що вона буде здійснювати дії, які будуть перешкоджати іiі викриттю.

Своєчасно здійснене затримання виключає для особи можливість сховатися від органів досудового розслідування, суду, продовжити злочинну діяльність, загрожувати учасникам процесу, іншими способами перешкоджати провадженню $[15$, с. 11]. Затримання особи має своїм завданням забезпечення короткочасної належної поведінки затриманого.

Інформація, що була добута під час затримання «на гарячому», якнайкраще характеризує підозрюваного, надає можливість припущення про його протиправні дії та подальшу можливу протиправну поведінку.

5. Створення умов для вирішення питання про застосування або зміну запобіжного заходу. У разі невиконання підозрюваним покладених на нього процесуальних обов'язків суд за клопотанням сторони обвинувачення своїм рішенням забезпечує явку підозрюваного / обвинуваченого на судове засідання із приводу обрання щодо нього запобіжного заходу.

У результаті затримання створюються необхідні умови для вирішення питання про обрання відносно затриманого запобіжного заходу у вигляді тримання під вартою, забезпечується виконання підозрюваним покладених на нього обов'язків у зв'язку з обранням запобіжного заходу [17, с. 93].

Автори Ю. В. Лук'яненко, О. О. Юхно пропонують унести зміни до ст. 208 КПК України, якими передбачити можливість затримання особи в разі порушення запобіжного заходу у вигляді домашнього арешту, оскільки наразі за умови безпосереднього виявлення такого порушення слідчий / прокурор не має права затримати таку особу [18, с. 82]. Тому є лише можливість звернення з відповідним клопотанням до слідчого судді про зміну запобіжного заходу. Таку пропозицію авторів ми повністю підтримуємо. Беручи до уваги, що такий запобіжний захід полягає в забороні покидати житло цілодобово чи в певний час доби й особі загрожує покарання - позбавлення волі, - то за умови порушення домашнього арешту є немалий ризик протидії досудовому розслідуванню. Контроль за поведінкою під час домашнього арешту покладено на органи Національної поліції. Виглядає нелогічним, що під час грубого порушення такого запобіжного заходу уповноважені службові особи позбавлені права на затримання. Марнувати час для звернення з відповідним клопотанням та отримання санкції суду $є$ не виправданим за такого становища.

Законодавством не передбачена така підстава для затримання особи, як оголошення іiі в розшук. Деякі автори (Д. М. Валігура, Ю.В.Лук'яненко, О.О.Юхно) пропонують ії закріпити на законодавчому рівні $[18$, с. $83 ; 19$, с. 12]. Такі пропозиції не виглядають доцільними, оскільки правовий механізм затримання такої особи існує. 3 огляду на те, що особу оголошено в розшук, вона має статус підозрюваного в провадженні. Отже, немає перепон для звернення до суду із клопотанням про обрання запобіжного заходу разом із клопотанням про дозвіл на затримання з метою приводу. За таких обставин особа буде затримана на підставі судового рішення.

Затримання особи задля вирішення питання про обрання запобіжного заходу забезпечує явку підозрюваного до суду. Закріплення такого положення в законодавстві виступає додатковою гарантією недопущення необгрунтованого обмеження прав і свобод особи внаслідок ії затримання [18, с. 125].

Висновки. У процесі дослідження було виділено п’ять функцій затримання особи в кримінальному провадженні:

1) припинення кримінальних правопорушень;

2) інформаційне забезпечення початкового етапу кримінальної процесуальної діяльності;

3) забезпечення проведення першочергових процесуальних дій за участю затриманого;

4) запобігання неналежній поведінці підозрюваного на первісному етапі розслідування;

5) створення умов для вирішення питання про застосування або зміну запобіжного заходу. 
Було надано процесуальну характеристику кожній iз них. Наведений у нашому дослідженні перелік функцій затримання не є вичерпним. Положення цієї роботи можуть слугувати базисом для подальших розробок стосовно функціонального призначення затримання особи в кримінальному провадженні.

Перспективними напрямками подальших досліджень можуть бути: 1) дослідження мети та підстав затримання особи в кримінальному провадженні; 2) надання процесуальної характеристики видам затримання особи в кримінальному провадженні.

\section{Список використаних джерел}

1. Кримінальний процесуальний кодекс України. Закон від 13.04.2012 № 4651-VI. Верховна Рада України. URL : https://zakon.rada.gov.ua/laws/show/4651-17 (дата звернення: 01.05.2020).

2. Конституція України. Закон від 28.06.1996 № 254к/96-BP. Верховна Рада України. URL : https://zakon.rada.gov.ua/laws/show/254\%D0\%BA/96-\%D0\%B2\%D1\%80 (дата звернення: 01.05.2020).

3. Конвенція про захист прав людини і основоположних свобод від 4 листопада 1950 p. URL : https://zakon.rada.gov.ua/laws/show/995_004 (дата звернення: 20.04.2020).

4. Бірюков В. П. Юридична природа затримання: постановка проблеми. Форум права. 2010. № 4. C. 81-89.

5. Борман В. I. Затримання як тимчасовий запобіжний захід. Актуальні питання кримінального процесу очима молодих дослідників : матеріали Х студентської наукової конференції (м. Харків, 15 травня 2014 року). Харків, 2014. 264 с.

6. Лазарева Д. В. Затримання уповноваженою службовою особою у кримінальному процесі України : монографія. Дніпро : Дніпроп. держ. ун-т внутр. справ, 2018. 188 с.

7. Волобуєв А. Ф. Етапи розслідування в криміналістичній методиці. Вісник університету внутрішніх справ. 1999. Вип. 5. С. 28-37.

8. Малярова В. О. Тактико-криміналістичні та процесуальні основи пошуку та затримання злочинця : автореф. дис. на здобуття наук. ступеня канд. юрид. наук : 12.00.09. Харків, 2005. 20 с.

9. Бузницька С. В. Затримання осіб, підозрюваних у вчиненні злочину: проблеми та пропозиції. Кримінальне право Украӥни. 2006. № 8. С. 28-33.

10. Смирнов А. М. Условия легитимности задержания лица, совершившего преступления, в зависимости от оснований этого задержания. Дневник науки. 2019. № 10 (34). 7 с. URL : https://www.elibrary.ru/download/elibrary_41319412_20668771.pdf (дата звернення: 01.05.2020).

11. Лоскутов Т. О. Кримінальне переслідування, здійснюване слідчим : монографія. Дніпропетровськ : Ліра ЛТД, 2011. 164 с.

12. Макаренко Є. І. Щодо мети затримання підозрюваного у вчиненні злочину. Право $i$ суспільство. 2013. № 6. С. 302-307.

13. Малярова В. О. Сутність затримання як слідчої дії. Вісник Харківського національного університету внутрішніх справ. 2000. С. 133-136.

14. Рожнова В. В. Щодо поняття «затримання осіб, підозрюваних у вчиненні злочину». Право Украӥни. № 8. 2001. С. 86-89.

15. Білоусов О. І., Смоков С. М. Затримання підозрюваного у кримінальному процесі України : монографія. Одеса : ОЮІ НУВС, 2009. 112 с.

16. Волобуєв А. Ф. Механізм злочину та його зв'язок з концептуальними положеннями криміналістики : монографія. Кривий Ріг : Вид. Р. А. Козлов, 2019. 122 с.

17. Шульга О. В. Затримання уповноваженою службовою особою у кримінальному провадженні : дис. на здобуття наук. ступеня канд. юрид. наук : 12.00.09. Київ, 2016. 255 с.

18. Лук'яненко Ю. В., Юхно О. О. Затримання особи як захід забезпечення кримінального провадження : монографія. Харків : Панов, 2016. 264 с.

19. Валігура Д. М. Оскарження до суду рішень, дій чи бездіяльності органу досудового розслідування та прокурора : автореф. дис. на здобуття наук. ступеня канд. юрид. наук : 12.00.09. Київ, 2013. 18 с.

\section{References}


1. Kryminalnyi protsesualnyi kodeks Ukrainy. Zakon vid 13.04.2012 № 4651-VI. Verkhovna Rada Ukrainy [Criminal Procedure Code of Ukraine]. URL : https://zakon.rada.gov.ua/laws/show/465117 (data zvernennia: 01.05.2020) [in Ukrainian].

2. Konstytutsiia Ukrainy. Zakon vid 28.06.1996 № 254k/96-VR. Verkhovna Rada Ukrainy [Constitution of Ukraine]. URL : https://zakon.rada.gov.ua/laws/show/254\%D0\%BA/96\%D0\%B2\%D1\%80 (data zvernennia: 01.05.2020) [in Ukrainian].

3. Konventsiia pro zakhyst prav liudyny i osnovopolozhnykh svobod vid 4 lystopada $1950 \mathrm{r}$. [Convention for the Protection of Human Rights and Fundamental Freedoms]. URL : https://zakon.rada.gov.ua/laws/show/995_004 (data zvernennia: 20.04.2020) [in Ukrainian].

4. Biriukov, V. P. (2010). Yurydychna pryroda zatrymannia: postanovka problemy. Forum prava [The legal nature of detention: problem statement]. № 4. S. 81-89 [in Ukrainian].

5. Borman, V. I. (2014). Zatrymannia yak tymchasovyi zapobizhnyi zakhid. Aktualni pytannia kryminalnoho protsesu ochyma molodykh doslidnykiv : materialy 5 studentskoi naukovoi konferentsii (m. Kharkiv, 15 travnia 2014 roku) [Detention as a temporary measure of restraint]. Kharkiv, $264 \mathrm{~s}$. [in Ukrainian].

6. Lazareva, D. V. (2018). Zatrymannia upovnovazhenoiu sluzhbovoiu osoboiu u kryminalnomu protsesi Ukrainy : monohrafiia [Detention by an authorized official in the criminal process of Ukraine : a monograph]. Dnipro : Dniprop. derzh. un-t vnutr. sprav, 188 s. [in Ukrainian].

7. Volobuiev, A. F. (1999). Etapy rozsliduvannia v kryminalistychnii metodytsi. Visnyk universytetu vnutrishnikh sprav [Stages of investigation in forensic methodology. Bulletin of the University of Internal Affairs]. Vyp. 5. S. 28-37 [in Ukrainian].

8. Maliarova, V. O. (2005). Taktyko-kryminalistychni ta protsesualni osnovy poshuku ta zatrymannia zlochyntsia : avtoref. dys. na zdobuttia nauk. stupenia kand. yuryd. nauk : 12.00 .09 [Tactical-criminological and procedural bases of search and detention of the criminal : the dissertation author's abstract 12.00.09]. Kharkiv, $20 \mathrm{~s}$. [in Ukrainian].

9. Buznytska, S. V. (2006). Zatrymannia osib, pidozriuvanykh u vchynenni zlochynu: problemy ta propozytsii. Kryminalne pravo Ukrainy [Detention of suspects: problems and suggestions. Criminal law of Ukraine]. № 8. S. 28-33 [in Ukrainian].

10. Smirnov, A. M. (2019). Usloviya legitimnosti zaderzhaniya lica, sovershivshego prestupleniya, v zavisimosti ot osnovanij etogo zaderzhaniya. Dnevnik nauki [The conditions for the legitimacy of the detention of the person who committed the crime, depending on the grounds for this detention. Diary of science]. № 10 (34). $7 \mathrm{~s}$. URL : https://www.elibrary.ru/download/elibrary_41319412_20668771.pdf (data zvernennya: 01.05.2020) [in Russian].

11. Loskutov, T. O. (2011). Kryminalne peresliduvannia, zdiisniuvane slidchym : monohrafiia [Criminal prosecution carried out by the investigator : monograph]. Dnipropetrovsk : Lira LTD, 164 s. [in Ukrainian].

12. Makarenko, Ye. I. (2013). Shchodo mety zatrymannia pidozriuvanoho u vchynenni zlochynu. Pravo i suspilstvo [Regarding the purpose of detaining a suspect in a crime. Law and society]. № 6 . S. 302-307 [in Ukrainian].

13. Maliarova, V. O. (2000). Sutnist zatrymannia yak slidchoi dii. Visnyk Kharkivskoho natsionalnoho universytetu vnutrishnikh sprav [The essence of detention as an investigative action. Bulletin of Kharkiv National University of Internal Affairs]. S. 133-136 [in Ukrainian].

14. Rozhnova, V. V. (2001). Shchodo poniattia «zatrymannia osib, pidozriuvanykh u vchynenni zlochynu». Pravo Ukrainy [Regarding the concept of "detention of persons suspected of committing a crime". Law of Ukraine]. № 8. S. 86-89 [in Ukrainian].

15. Bilousov, O. I., Smokov, S. M. (2009). Zatrymannia pidozriuvanoho u kryminalnomu protsesi Ukrainy : monohrafiia [Detention of a suspect in the criminal process of Ukraine: a monograph]. Odesa : OIuI NUVS, 112 s. [in Ukrainian].

16. Volobuiev, A. F. (2019). Mekhanizm zlochynu ta yoho zviazok z kontseptualnymy polozhenniamy kryminalistyky : monohrafiia [The mechanism of crime and its connection with the conceptual provisions of criminology : a monograph]. Kryvyi Rih : Vyd. R. A. Kozlov, $122 \mathrm{s.}$ [in Ukrainian].

17. Shulha, O. V. (2016). Zatrymannia upovnovazhenoiu sluzhbovoiu osoboiu u kryminalnomu provadzhenni : dys. na zdobuttia nauk. stupenia kand. yuryd. nauk : 12.00 .09 [Detention by an authorized 
official in criminal proceedings : dis. for science. degree of Cand. jurid. Science : 12.00.09]. Kyiv, 255 s. [in Ukrainian].

18. Lukianenko, Yu. V., Yukhno, O. O. (2016). Zatrymannia osoby yak zakhid zabezpechennia kryminalnoho provadzhennia : monohrafiia [Detention of a person as a measure to ensure criminal proceedings : a monograph]. Kharkiv : Panov, 264 s. [in Ukrainian].

19. Valihura, D. M. (2013). Oskarzhennia do sudu rishen, dii chy bezdiialnosti orhanu dosudovoho rozsliduvannia ta prokurora : avtoref. dys. na zdobuttia nauk. stupenia kand. yuryd. nauk : 12.00.09 [Appeal to the court of decisions, actions or inaction of the pre-trial investigation body and the prosecutor : author's ref. dis. for science. degree of Cand. jurid. Science : 12.00.09]. Kyiv, $18 \mathrm{~s}$. [in Ukrainian].

\author{
Pototskyi Myroslav, \\ Postgraduate \\ (Donetsk Law Institute, MIA of Ukraine, Kryvyi Rih) \\ ORCID: https://orcid.org/0000-0002-2979-9114
}

\title{
FUNCTIONALITY OF CRIMINAL PROCEDURAL DETENTION
}

The article focuses on the study of the functional purpose of detention of a person in criminal proceedings. It is emphasized that the detention of a person is a necessary element of criminal procedure. Without detention measures, the prosecution will lose an effective tool to influence procedural issues, which in turn will result in unjustified difficulties in prosecuting individuals. The detention of a person restricts fundamental human rights: the right to liberty and security of person. Therefore, the arrest procedures should be regulated in detail in national law. When posing the problem, it is noted that a misunderstanding of the functionality of detention can have a negative impact on the observance of individual rights and freedoms. The study of the functional purpose of detention is necessary to understand the essence of the use of detention in criminal proceedings. In the process of covering the topic, it is noted that despite the availability of scientific works on the study of detention of a person in criminal proceedings, the issues concerning the functional purpose of detention of a person remain unresolved. There are five functions of criminal procedural detention: cessation of criminal offenses; information support for the initial stage of criminal procedural activity; ensuring priority proceedings with the participation of the detainee; prevention of inappropriate behavior of the suspect at the initial stage of the investigation; the creation of conditions for resolving the issue of applying or changing the preventative measure. During the presentation of the basic material the procedural characteristic of functions of detention of the person is given. Promising directions for further researches can be the following: research of the purpose and the bases of detention of the person in criminal proceedings; study of the stages of detention of a person in criminal proceedings; providing procedural characteristics of the types of detention of a person in criminal proceedings; research on the protection of the rights of a detainee.

Key words: detention; suspect; functionality; authorized official; crime; cessation.

Надійшла до редколегії 26.05.2020 